\title{
Perceived satisfaction with HIV care and its association with adherence to antiretroviral therapy and viral suppression in the African Cohort Study
}

Nancy Somi ${ }^{1,2}$, Nicole Dear ${ }^{2,3}$, Domonique Reed ${ }^{2,3}$, Ajay Parikh ${ }^{2,3}$, Anange Lwilla1,2, Emmanuel Bahemana ${ }^{1,2}$, Samoel Khamadi ${ }^{1,2}$, Michael Iroezindu ${ }^{2,4}$, Hannah Kibuuka ${ }^{5}$, Jonah Maswai ${ }^{2,6}$, Trevor A. Crowell ${ }^{2,3}$, John Owuoth ${ }^{7,8}$, Lucas Maganga ${ }^{9}$, Christina Polyak ${ }^{2,3}$, Julie Ake ${ }^{2}$ and Allahna Esber ${ }^{2,3^{*}}$ (D) on behalf of the AFRICOS Study Group

\begin{abstract}
Background: Increased availability of HIV care over the past decade has dramatically reduced morbidity and mortality among people living with HIV (PLWH) in sub-Saharan Africa. However, perceived and experienced barriers to care, including dissatisfaction with services, may impact adherence and viral suppression. We examined the associations between satisfaction with HIV care and antiretroviral therapy (ART) adherence and viral load suppression.

Methods: The African Cohort Study (AFRICOS) is a prospective observational study conducted at PEPFAR-supported clinics in four African countries. At enrollment and twice-yearly study visits, participants received a clinical assessment and a socio-behavioral questionnaire was administered. Participants were classified as dissatisfied with care if they reported dissatisfaction with any of the following: waiting time, health care worker skills, health care worker attitudes, quality of clinic building, or overall quality of care received. Robust Poisson regression was used to estimate prevalence ratios and 95\% confidence intervals (Cls) for associations between satisfaction with care and ART adherence and between satisfaction with care and viral suppression (viral load < 1000 copies $/ \mathrm{mL}$ ).

Results: As of 1 March 2020, 2928 PLWH were enrolled and 2311 had a year of follow-up visits. At the first annual follow-up visit, 2309 participants responded to questions regarding satisfaction with quality of care, and 2069 (89.6\%) reported satisfaction with care. Dissatisfaction with waiting time was reported by 177 (7.6\%), building quality by 59 $(2.6 \%)$, overall quality of care by $18(0.8 \%)$, health care worker attitudes by $16(0.7 \%)$, and health care worker skills by 15 (0.7\%). After adjusting for age and site, there was no significant difference in viral suppression between those who were satisfied with care and those who were dissatisfied (aPR: 1.03, 95\% Cl 0.97-1.09). Satisfaction with HIV care was moderately associated with ART adherence among AFRICOS participants (aPR: 1.09; 95\% Cl 1.00-1.16).
\end{abstract}

Conclusions: While patient satisfaction in AFRICOS was high and the association between perceived quality of care and adherence to ART was marginal, we did identify potential target areas for HIV care improvement, including reducing clinic waiting times.

\footnotetext{
*Correspondence: aesber@hivresearch.org

${ }^{3}$ Henry M. Jackson Foundation for the Advancement of Military Medicine Inc., 6720a Rockledge Drive, Suite 400, Bethesda, MD 20817, USA

Full list of author information is available at the end of the article
} permits use, sharing, adaptation, distribution and reproduction in any medium or format, as long as you give appropriate credit to the original author(s) and the source, provide a link to the Creative Commons licence, and indicate if changes were made. The images or other third party material in this article are included in the article's Creative Commons licence, unless indicated otherwise in a credit line to the material. If material is not included in the article's Creative Commons licence and your intended use is not permitted by statutory regulation or exceeds the permitted use, you will need to obtain permission directly from the copyright holder. To view a copy of this licence, visit http://creativecommons.org/licenses/by/4.0/. The Creative Commons Public Domain Dedication waiver (http://creativeco mmons.org/publicdomain/zero/1.0/) applies to the data made available in this article, unless otherwise stated in a credit line to the data. 
Keywords: HIV/AIDS, Quality of care, Viral load

\section{Background}

The widespread rollout and use of antiretroviral therapy (ART) in sub-Saharan Africa in the last two decades remains a monumental public health achievement [1]. Effective ART has made an impact on the clinical course of HIV infection, and has reduced disease progression, incidence of opportunistic infections, and mortality in sub-Saharan Africa [2]. While use of ART has led to a dramatic decrease in morbidity and mortality, nonadherence remains a major challenge [3].

The third component of the UNAIDS 95-95-95 target, viral load suppression for $95 \%$ of people living with HIV (PLWH) on ART [4], is directly linked to ART adherence. Nonadherence to ART and uncontrolled viremia remain a major cause of HIV-related morbidity and mortality [5], and have the potential to impede progress towards the third 95. Several studies have identified factors associated with nonadherence, including lack of self-motivation or diagnosis acceptance, socio-economic status, forgetfulness, lack of social support and lack of trust in a care provider [6-9]. A cohort study across six African countries found additional barriers to adherence as self-reported by PLWH, including sickness or adverse events, pharmacy stock outs, stigma or depression, pill burden and regimen complexity [10]. Quality and holistic care for PLWH is key to sustaining high levels of adherence and long-term viral suppression [11].

As well-established HIV care and treatment programs transition from rapid ART scale-up [12], it is increasingly recognized that quality improvements can help close gaps along the care cascade and improve clinical outcomes $[13,14]$. A systematic review by Hargreaves et al., found that quality improvement initiatives in HIV programs in low and middle income countries contributed most to ART uptake, ART adherence and viral suppression, within the context of national policy and program changes [13]. Importantly, patient satisfaction and perceived quality of care, including in regards to health personnel proficiency, healthcare delivery, sufficiency of resources and services, accessibility and cost of care, are important to the overall wellbeing of PLWH $[15,16]$. Variable evidence about which aspects of quality interventions lead to the greatest improvements of care suggest that better standardization and further research is needed [13].

Given the suggested relationship between satisfaction with HIV care, adherence, and viral suppression, improving the quality of HIV care in sub-Saharan Africa may help shrink existing gaps in achieving the UNAIDS
95-95-95 targets [4]. We assessed the association between satisfaction with HIV care and adherence to ART and viral load suppression in four African countries.

\section{Methods}

\section{Study design and participants}

As previously described, the African Cohort Study (AFRICOS) is an ongoing prospective cohort study enrolling PLWH and HIV uninfected adult participants at 12 President's Emergency Plan for AIDS Relief (PEPFAR)-supported HIV care and treatment clinics across five study sites in four countries: Tanzania, Kenya (Kisumu and South Rift Valley) Uganda and Nigeria [17]. PLWH were selected randomly from current client lists, with a small subset recruited from prior HIV research studies. All non-pregnant, non-incarcerated adults age 18 years and older consenting to data and specimen collection were eligible for inclusion.

The study was approved by the institutional review boards of the Walter Reed Army Institute of Research (\#1897), Makerere University School of Public Health (\#173), Uganda National Committee of Science and Technology (HS-1175), Kenya Medical Research Institute Science and Ethics Review Unit (SSC\# 2396, 2371), Tenwek Institutional Ethics Review Committee (SSC\# 2371), Tanzania National Institute of Medical Research (NIMR/ HQ/R.8a/Vol.1X/1060), Mbeya Medical and Research Ethics Committee (NIMR/HQ/R.8a/Vol.1X/1060), and Ministry of Defense Health Research and Ethics Committee (\#3726112019). All participants gave written informed consent.

\section{Data collection and measures}

At enrollment and twice-yearly study visits, participants received a clinical assessment and a structured sociobehavioral questionnaire was administered by trained clinic staff through face to face interviews. The subject questionnaire collected data on demographics, including age, sex, employment status, educational attainment, food security (defined as having enough food to eat in the past 12 months), and healthcare accessibility (defined as distance from facility).

Participants were asked a series of questions regarding their satisfaction with services received at the ART clinic. Topics included satisfaction with the following: waiting time, health care worker skills, health care worker attitudes, quality of clinic building, and overall quality of care received (Additional file 1: Fig. S1). For these analyses, perception on quality of care was measured as either 
satisfied or dissatisfied. Participants were classified as dissatisfied with care if they reported dissatisfaction with any of the items.

ART adherence was based on the self-reported number of doses missed in the past 30 days. Participants were classified as nonadherent if that had missed one or more doses in the past 30 days. Viral suppression was defined as a viral load $<1000$ copies $/ \mathrm{mL}$.

Data were captured on paper case report forms then entered and verified in the ClinPlus platform (Anju Software, Tempe, AZ).

\section{Statistical analyses}

Chi-squared and Wilcoxon rank sum tests were used to describe significant differences in participant satisfaction by select demographic and HIV-related characteristics at the first annual visit after enrollment. Generalized linear models with a Poisson distribution and robust standard errors were used to estimate unadjusted and adjusted prevalence ratios (aPRs) and 95\% confidence intervals (95\% CIs) for associations between satisfaction with care and ART adherence and between satisfaction with care and viral suppression. Confounding was assessed using a $10 \%$ change in coefficients. Each model was restricted to observations with non-missing data for all variables included in the unadjusted and adjusted models.

All analyses were performed in SAS version 9.4 (SAS Institute, Cary, North Carolina) and Stata version 16.0 (StataCorp, College Station, Texas) software.

\section{Results}

\section{Study population characteristics}

As of March 1, 2020, 2928 PLWH were enrolled in the African Cohort Study with 2311 having at least 1 year of follow-up visits. Of these, 2309 participants responded to questions regarding satisfaction with quality of care at the HIV care and treatment clinics at the first annual follow up-visit. The median age was 40.3 (interquartile range [IQR]: 33.5-47.7) years and 1351 (58.5\%) were female (Table 1). Most participants had a primary level education or less $(n=1390,60.2 \%), 1378$ (59.7\%) were unemployed, and 1602 (69.4\%) had enough food to eat in the past 12 months. Participants lived a median of $8 \mathrm{~km}$ from their HIV care facility (IQR: $4.5-16 \mathrm{~km}$ ) and distance did not differ significantly by satisfaction with care. Overall, the median time since HIV diagnosis was 4.1 (IQR: 1.4-7.5) years and median time on ART was 2.5 (IQR: 1.1-6.1) years.

\section{AFRICOS participants' perception on quality of HIV care} Overall, 2069 (89.6\%) reported being satisfied with their HIV care while 240 (10.4\%) reported dissatisfaction with at least one of the indicators at their first annual follow-up visit (Table 1). Satisfaction with care did not vary by sex, with $104(10.9 \%)$ males and $136(10.1 \%)$ females reporting dissatisfaction with HIV care $(\mathrm{p}=0.54)$. As compared to unemployed participants, a greater proportion of participants who were employed reported being dissatisfied with care $(54.2 \%$ vs. $45.8 \%, \mathrm{p}<0.001)$. A greater proportion of those with a secondary level education or above were dissatisfied as compared to those with primary level education or less $(51.7 \%$ vs. $48.3 \%, \mathrm{p}<0.001)$. As compared to those who did not have enough food to eat in the past 12 months, a greater proportion of those who had enough food to eat in the past 12 months reported dissatisfaction with care $(75.4 \%$ vs. $24.2 \%, \mathrm{p}=0.03)$. Satisfaction with care also varied significantly by study site $(\mathrm{p}<0.001)$. The primary driver of dissatisfaction was waiting time $(\mathrm{n}=177,7.7 \%)$, followed by building quality $(\mathrm{n}=59,2.6 \%)$, overall quality of care $(\mathrm{n}=18,0.8 \%)$, health care workers attitudes $(n=16,0.7 \%)$, and health care worker skills ( $n=15,0.7 \%$; Table 2). Examining each individual component of dissatisfaction with care, study site differed significantly among those dissatisfied with waiting time, building quality, health care workers attitudes, and health care worker skills (Additional file 1: Table S1).

\section{Quality of care, viral suppression and ART adherence}

Satisfaction with care was associated with ART adherence in the unadjusted models (PR: 1.15; 95\% CI 1.061.24; Table 3 ). Though slightly attenuated, the association remained moderately significant after adjustment for study site and age (aPR: 1.08; 95\% CI 1.00-1.16).

Among participants included in these analyses, $87.5 \%$ were virally suppressed at their first annual follow-up visit. Satisfaction with care was not associated with viral suppression in the unadjusted models (PR: 1.04, 95\% CI 0.98-1.11; Table 4), and remained nonsignificant after adjustment for study site and age (aPR: 1.03, 95\% CI 0.97-1.09).

\section{Discussion}

High quality HIV care in ART clinics is just as important as diagnosing, treating, preventing and controlling the disease in African countries as advocated by UNAIDS in 2014. Although African governments, assisted by donors and funders, are working hard to end the AIDS epidemic by 2030 , little has been said about the quality of care provided by ministries of health [4]. Consistent with findings from similar studies, we found that the majority of AFRICOS study participants were satisfied with the quality of care they received [15]. A comparable study done in South Africa among 20 PLWH revealed similarly low levels of dissatisfaction [2]. A cross-sectional survey conducted in Nigeria assessing overall quality of care, staff 
Table 1 Characteristics of PLWH by perceived satisfaction with care at first annual visit after enrollment

\begin{tabular}{|c|c|c|c|c|}
\hline & $\begin{array}{l}\text { All participants } \\
(\mathrm{n}=2309)\end{array}$ & $\begin{array}{l}\text { Dissatisfied } \\
(n=240)\end{array}$ & $\begin{array}{l}\text { Satisfied } \\
(n=2069)\end{array}$ & P-value \\
\hline Study site & & & & $<0.001$ \\
\hline Kayunga, Uganda & $421(18.2 \%)$ & $53(22.1 \%)$ & $368(17.8 \%)$ & \\
\hline South Rift Valley, Kenya & $825(35.7 \%)$ & $41(17.1 \%)$ & $784(37.9 \%)$ & \\
\hline Kisumu West, Kenya & 460 (19.9\%) & $28(11.7 \%)$ & 432 (20.9\%) & \\
\hline Mbeya, Tanzania & $411(17.8 \%)$ & $68(28.3 \%)$ & $343(16.6 \%)$ & \\
\hline Abuja \& Lagos Nigeria & $192(8.3 \%)$ & $50(20.8 \%)$ & $142(6.9 \%)$ & \\
\hline Age (years) & & & & 0.69 \\
\hline $18-29$ & $323(14.0 \%)$ & $39(16.3 \%)$ & $284(13.7 \%)$ & \\
\hline $30-39$ & $802(34.7 \%)$ & $78(32.5 \%)$ & $724(35.0 \%)$ & \\
\hline $40-49$ & $720(31.2 \%)$ & $73(30.4 \%)$ & $647(31.3 \%)$ & \\
\hline $50+$ & $464(20.1 \%)$ & $50(20.8 \%)$ & 414 (20.0\%) & \\
\hline Sex & & & & 0.54 \\
\hline Male & $958(41.5 \%)$ & $104(43.3 \%)$ & $854(41.3 \%)$ & \\
\hline Female & $1351(58.5 \%)$ & $136(56.7 \%)$ & $1215(58.7 \%)$ & \\
\hline Currently employed & & & & $<0.001$ \\
\hline No & 1378 (59.7\%) & $110(45.8 \%)$ & $1268(61.3 \%)$ & \\
\hline Yes & $931(40.3 \%)$ & $130(54.2 \%)$ & 801 (38.7\%) & \\
\hline Education & & & & $<0.001$ \\
\hline Primary or less & $1390(60.2 \%)$ & $116(48.3 \%)$ & $1274(61.6 \%)$ & \\
\hline Secondary or above & $919(39.8 \%)$ & $124(51.7 \%)$ & 795 (38.4\%) & \\
\hline Enough food to eat in past 12 months & & & & 0.03 \\
\hline No & $706(30.6 \%)$ & $58(24.2 \%)$ & $648(31.3 \%)$ & \\
\hline Yes & $1602(69.4 \%)$ & $181(75.4 \%)$ & $1421(68.7 \%)$ & \\
\hline Missing & $1(<1 \%)$ & $1(0.4 \%)$ & $0(0.0 \%)$ & \\
\hline Distance from facility (km), median (IQR) & $8(4.5-16.0)$ & $9(4.5-20.0)$ & $8(4.5-16.0)$ & 0.78 \\
\hline Time since HIV diagnosis & & & & 0.09 \\
\hline$<1$ year & $27(1.2 \%)$ & $3(1.3 \%)$ & $24(1.2 \%)$ & \\
\hline 1 to 4 years & $1250(54.1 \%)$ & $137(57.1 \%)$ & $1113(53.8 \%)$ & \\
\hline 5 to 9 years & $789(34.2 \%)$ & $68(28.3 \%)$ & $721(34.8 \%)$ & \\
\hline 10 or more years & $218(9.4 \%)$ & $31(12.9 \%)$ & 187 (9.0\%) & \\
\hline Missing & $25(1.1 \%)$ & $1(0.4 \%)$ & $24(1.2 \%)$ & \\
\hline Duration on ART & & & & 0.03 \\
\hline ART naïve & $131(5.7 \%)$ & $16(6.7 \%)$ & $115(5.6 \%)$ & \\
\hline$<6$ months & $79(3.4 \%)$ & $16(6.7 \%)$ & $63(3.0 \%)$ & \\
\hline 6 months to $<2$ years & $889(38.5 \%)$ & $82(34.2 \%)$ & 807 (39.0\%) & \\
\hline 2 years to $<4$ years & $341(14.8 \%)$ & $32(13.3 \%)$ & 309 (14.9\%) & \\
\hline$\geq 4$ years & $854(37.0 \%)$ & $92(38.3 \%)$ & $762(36.8 \%)$ & \\
\hline Missing & $15(0.6 \%)$ & $2(0.8 \%)$ & $13(0.6 \%)$ & \\
\hline
\end{tabular}

All data are presented as $n$ (column percentage). P-values were calculated using Pearson's chi-squared tests or Wilcoxon rank sum tests for continuous variables. Bold indicates significance at $p<0.05$

attitude, confidentiality, distance to and time spent at facility indicated that PLWH were highly satisfied with overall quality of care and those who were dissatisfied with confidentiality and staff attitude had lower odds of satisfaction with overall quality of care [18].

Among participants dissatisfied with care, waiting time was given as the top reason. Waiting time was also reported by ART users at some ART facilities in Botswana, Ghana, Tanzania and Uganda as one of the main obstacles to optimal adherence [3,19-21]. A study conducted among 408 PLWH in Nigeria indicates that participants are satisfied with care in general but not waiting time (73\%) [22]. Another study conducted among PLWH who attended HIV private clinics in Dar-es- Salaam, 
Table 2 Proportion of participants dissatisfied with individual components of HIV care services

\begin{tabular}{lcc}
\hline & $\mathbf{n = 2 3 0 9}$ & \% \\
\hline Waiting time & 177 & 7.66 \\
Building quality & 59 & 2.55 \\
Overall quality of care & 18 & 0.78 \\
Healthcare workers attitudes & 16 & 0.69 \\
Healthcare worker skills & 15 & 0.65 \\
\hline
\end{tabular}

Tanzania found that 19\% wanted decreased waiting times despite waiting for less than $1 \mathrm{~h}$ [23]. This can be explained by the fact that most private clinics have shorter waiting times and are quick at responding to user needs compared to public clinics $[24,25]$. To rectify long waiting times, studies suggest employing more staff members and scheduling patients at different times of the day [26]. Entertainment will also enable patients to stay engaged and wait actively; some suggested forms of entertainment are television, music and providing informational health reading materials [27, 28]. Reducing clinic waiting time or providing engaging waiting room activities could have downstream effects on ART adherence and overall health outcomes for PLWH.

Another component of care that participants reported dissatisfaction with was healthcare worker skills and attitudes. A similar study done in Singapore confirmed patients filed complaints which indicated dissatisfaction with doctors' attitude/conduct $(28.8 \%)$ and professional skills (17.8\%) [20]. In this study, most participants reported being satisfied with care, but several had negative experiences regarding health care providers' skills or attitudes, providing a specific target for improvement during healthcare worker training.

Study findings indicated no association between perceived quality of care and viral load suppression among AFRICOS participants. In contrast, a cross-sectional study conducted in Houston, Texas at an ART primary care clinic found that patients who were satisfied with care had higher odds of viral suppression compared to those who were not [29]. Perceived care may also indirectly affect viral suppression in situations where patients do not trust their care givers or were not satisfied with care, consequently missing care visits. Longer time spent without seeing physicians resulted in reduced viral suppression $[29,30]$.

Satisfaction with care was moderately associated with ART adherence in AFRICOS. This finding aligns with other settings where satisfaction with care influenced adherence. In Manaus, Brazil participants who rated the quality of care highly were approximately two times more likely to adhere to care than those who did
Table 3 Unadjusted and adjusted PR for association between satisfaction with care and ART adherence at first annual visit after enrollment

\begin{tabular}{|c|c|c|}
\hline & PR $(95 \% \mathrm{Cl})$ & aPR $(95 \% \mathrm{Cl})$ \\
\hline \multicolumn{3}{|l|}{ Satisfaction with care } \\
\hline Needs improvement & Ref & - \\
\hline Doesn't need improvement & $1.15(1.06-1.24)$ & $1.08(1.00-1.16)$ \\
\hline \multicolumn{3}{|l|}{ Study site } \\
\hline Kayunga, Uganda & Ref & - \\
\hline South Rift Valley, Kenya & $1.17(1.11-1.23)$ & $1.16(1.09-1.22)$ \\
\hline Kisumu West, Kenya & $1.09(1.03-1.16)$ & $1.09(1.03-1.16)$ \\
\hline Mbeya, Tanzania & $1.03(0.96-1.10)$ & $1.03(0.97-1.11)$ \\
\hline Abuja \& Lagos Nigeria & $0.80(0.72-0.91)$ & $0.81(0.72-0.91)$ \\
\hline \multicolumn{3}{|l|}{ Age (years) } \\
\hline $18-29$ & Ref & - \\
\hline $30-39$ & $1.04(0.98-1.11)$ & $1.04(0.97-1.11)$ \\
\hline $40-49$ & $1.10(1.03-1.17)$ & $1.09(1.03-1.16)$ \\
\hline $50+$ & $1.11(1.04-1.18)$ & $1.08(1.02-1.15)$ \\
\hline \multicolumn{3}{|l|}{ Sex } \\
\hline Male & Ref & \\
\hline Female & $1.01(0.97-1.04)$ & \\
\hline \multicolumn{3}{|l|}{ Currently employed } \\
\hline No & Ref & \\
\hline Yes & $0.90(0.87-0.94)$ & \\
\hline \multicolumn{3}{|l|}{ Education } \\
\hline Primary or less & Ref & \\
\hline Secondary or above & $0.98(0.95-1.02)$ & \\
\hline \multicolumn{3}{|l|}{$\begin{array}{l}\text { Enough food to eat in past } 12 \\
\text { months }\end{array}$} \\
\hline No & Ref & \\
\hline Yes & $0.98(0.94-1.01)$ & \\
\hline Distance from facility (km) & $1.00(1.00-1.00)$ & \\
\hline \multicolumn{3}{|l|}{ Time since HIV diagnosis } \\
\hline$<1$ year & Ref & \\
\hline 1 to 4 years & $1.06(0.86-1.31)$ & \\
\hline 5 to 9 years & $1.11(0.90-1.37)$ & \\
\hline 10 or more years & $1.12(0.91-1.38)$ & \\
\hline \multicolumn{3}{|l|}{ Duration on ART } \\
\hline ART naïve & Ref & \\
\hline$<6$ months & $0.91(0.85-0.98)$ & \\
\hline 6 months to $<2$ years & $0.83(0.81-0.86)$ & \\
\hline 2 years to $<4$ years & $0.84(0.80-0.88)$ & \\
\hline$\geq 4$ years & $0.89(0.87-0.91)$ & \\
\hline
\end{tabular}

Robust Poisson regression was used to estimate prevalence ratios and 95\% confidence intervals $(\mathrm{Cls})$ for associations between satisfaction with care and ART adherence. Bold indicates significance at $p<0.05$

not. In this study predictors of satisfaction with care included convenient location of the clinic, waiting time, and respectful treatment from the nurses [31]. These results are also comparable to the cross sectional study conducted in Houston, Texas where participants with 
Table 4 Unadjusted and adjusted PR for association between satisfaction with care and viral suppression at first annual visit after enrollment

\begin{tabular}{|c|c|c|}
\hline & PR (95\% Cl) & aPR $(95 \% \mathrm{Cl})$ \\
\hline \multicolumn{3}{|l|}{ Satisfaction with care } \\
\hline Needs improvement & Ref & - \\
\hline Doesn't need improvement & $1.04(0.98-1.11)$ & $1.03(0.97-1.09)$ \\
\hline \multicolumn{3}{|l|}{ Study site } \\
\hline Kayunga, Uganda & Ref & - \\
\hline South Rift Valley, Kenya & $1.05(1.00-1.10)$ & $1.04(0.99-1.09)$ \\
\hline Kisumu West, Kenya & $1.07(1.01-1.12)$ & $1.06(1.01-1.12)$ \\
\hline Mbeya, Tanzania & $0.96(0.91-1.02)$ & $0.96(0.91-1.02)$ \\
\hline Abuja \& Lagos Nigeria & $1.02(0.95-1.09)$ & $1.01(0.95-1.09)$ \\
\hline \multicolumn{3}{|l|}{ Age (years) } \\
\hline 18-29 & Ref & - \\
\hline $30-39$ & $1.04(0.98-1.10)$ & $1.03(0.97-1.10)$ \\
\hline $40-49$ & $1.11(1.05-1.17)$ & $1.10(1.04-1.17)$ \\
\hline $50+$ & $1.10(1.03-1.17)$ & $1.09(1.03-1.16)$ \\
\hline \multicolumn{3}{|l|}{ Sex } \\
\hline Male & Ref & \\
\hline Female & $0.98(0.95-1.01)$ & \\
\hline \multicolumn{3}{|l|}{ Currently employed } \\
\hline No & Ref & \\
\hline Yes & $1.00(0.97-1.03)$ & \\
\hline \multicolumn{3}{|l|}{ Education } \\
\hline Primary or less & Ref & \\
\hline Secondary or above & $1.00(0.96-1.03)$ & \\
\hline \multicolumn{3}{|l|}{$\begin{array}{l}\text { Enough food to eat in past } 12 \\
\text { months }\end{array}$} \\
\hline No & Ref & \\
\hline Yes & $0.99(0.95-1.02)$ & \\
\hline Distance from facility (km) & $1.00(1.00-1.00)$ & \\
\hline \multicolumn{3}{|l|}{ Time since HIV diagnosis } \\
\hline$<1$ year & Ref & \\
\hline 1 to 4 years & $1.16(0.92-1.47)$ & \\
\hline 5 to 9 years & $1.24(0.98-1.57)$ & \\
\hline 10 or more years & $1.23(0.97-1.56)$ & \\
\hline \multicolumn{3}{|l|}{ Duration on ART } \\
\hline ART naïve & Ref & \\
\hline$<6$ months & $4.40(3.13-6.18)$ & \\
\hline 6 months to $<2$ years & $4.28(3.06-5.99)$ & \\
\hline 2 years to $<4$ years & $4.36(3.11-6.10)$ & \\
\hline$\geq 4$ years & $4.27(3.05-5.98)$ & \\
\hline
\end{tabular}

Robust Poisson regression was used to estimate prevalence ratios and $95 \%$ confidence intervals ( $\mathrm{Cls}$ ) for associations between satisfaction with care and viral suppression (viral load $<1000$ copies $/ \mathrm{mL}$ ). Bold indicates significance at $\mathrm{p}<0.05$

high scores of satisfaction were more likely to adhere to care $(\mathrm{p}<0.0001)$ [29]. Conversely a study conducted in the midwestern United States suggests that the majority of PLWH come to clinics based on their own motivation and consideration for their health rather than quality of care and influence from health care workers, thus it is not surprising we also did not detect a strong signal [7].

Limitations of this study include that the data around satisfaction with care were ascertained through faceto-face interviews with care providers, thus social desirability bias may have influenced how AFRICOS participants responded to these questions. Furthermore, participants enrolled in a longitudinal cohort study may receive enhanced attention and support and may not be representative of the general clinic populations in these settings. The existing survey only assessed summary measures of satisfaction and thus we were not able to delve into detailed aspects such as specific services provided by the health care worker. Future research should focus on other aspects of HIV care as well as explore country level differences that may impact on quality of HIV care and clinical outcomes differentially.

\section{Conclusions}

Satisfaction with HIV care was reported by a majority of study participants at first annual follow-up visit. While there was no significant association between satisfaction and viral suppression and only a marginal association between satisfaction and ART adherence, reductions in clinic waiting time as well as improvements to healthcare worker training and proficiency may provide additional benefit to PLWH and HIV care programs overall. Rigorous and routine program evaluations are needed to ensure quality improvement initiatives translate into positive patient level and programmatic outcomes.

\section{Supplementary Information}

The online version contains supplementary material available at https://doi. org/10.1186/s12981-021-00414-3.

Additional file 1: Figure 1. Participants were asked a series of questions regarding their satisfaction with services received at the ART clinic. Table 1. Characteristics of PLWH by dissatisfaction with individual components of care at first annual visit after enrollment.

\section{Acknowledgements}

We thank the study participants, local implementing partners, and hospital leadership at Kayunga District Hospital, Kericho District Hospital, AC Litein Mission Hospital, Kapkatet District Hospital, Tenwek Mission Hospital, Kapsabet District Hospital, Nandi Hills District Hospital, Kisumu West District Hospital, Mbeya Zonal Referral Hospital, Mbeya Regional Referral Hospital, Defence Headquarters Medical Center, and the 68th Nigerian Army Reference Hospital. We would also like to thank the AFRICOS Study Group - from the US Military HIV Research Program Headquarters team: Danielle Bartolanzo, Alexus Reynolds, Katherine Song, Mark Milazzo, Leilani Francisco, Shauna Mankiewicz, Steven Schech, Alexandra Golway, Badryah Omar, Tsedal Mebrahtu, Elizabeth Lee, Kimberly Bohince, Jaclyn Hern, Emma Duff, Kara Lombardi, Michelle Imbach, and Leigh Anne Eller; from the AFRICOS Uganda team: Michael Semwogerere, Prossy Naluyima, Godfrey Zziwa, Allan Tindikahwa, Hilda Mutebe, Cate Kafeero, Enos Baghendaghe, William Lwebuge, Freddie Ssentogo, Hellen Birungi, Josephine Tegamanyi, Paul Wangiri, Christine Nabanoba, Phiona 
Namulondo, Richard Tumusiime, Ezra Musingye, Christina Nanteza, Joseph Wandege, Michael Waiswa, Evelyn Najjuma, Olive Maggaga, Isaac Kato Kenoly, and Barbara Mukanza; from the AFRICOS South Rift Valley, Kenya team: Rither Langat, Aaron Ngeno, Lucy Korir, Raphael Langat, Francis Opiyo, Alex Kasembeli, Christopher Ochieng, Japhet Towett, Jane Kimetto, Brighton Omondi, Mary Leelgo, Michael Obonyo, Linner Rotich, Enock Tonui, Ella Chelangat, Joan Kapkiai, Salome Wangare, Zeddy Bett Kesi, Janet Ngeno, Edwin Langat, Kennedy Labosso, Joshua Rotich, Leonard Cheruiyot, Enock Changwony, Mike Bii, Ezekiel Chumba, Susan Ontango, Danson Gitonga, Samuel Kiprotich, Bornes Ngtech, Grace Engoke, Irene Metet, Alice Airo, and Ignatius Kiptoo; from the AFRICOS Kisumu, Kenya team: Valentine Sing'oei, Winne Rehema, Solomon Otieno, Celine Ogari, Elkanah Modi, Oscar Adimo, Charles Okwaro, Christine Lando, Margaret Onyango, Iddah Aoko, Kennedy Obambo, Joseph Meyo, and George Suja; from the AFRICOS Abuja, Nigeria team: Nnamdi Azuakola, Mfreke Asuquo, Abdulwasiu Bolaji Tiamiyu, Afoke Kokogho, Samirah Sani Mohammed, Ifeanyi Okoye, Sunday Odeyemi, Aminu Suleiman, Lawrence Umeji, Onome Enas, Miriam Mbachu, ljeoma Chigbu-Ukaegbu, Wilson Adai, Felicia Anayochukwu Odo, Rabi Abdu, Rosemary Akiga, Helen Nwandu, Chisara Okolo, Ndubuisis Okeke; from the AFRICOS Lagos, Nigeria team: Zahra Parker, Asogwa Ugochukwu Linus, Concilia Amaka Agbaim, Tunde Adegbite, Nkenchiere Harrison, Adewale Adelakun, Ekeocha Chioma, Victoria Idi, Rachel Eluwa, Jumoke Nwalozie, lgiri Faith, Blessing Okanigbuan, Achugwo Emmanuel, Nkiru Nnadi, Ndubuisi Rosemary, Uzoegwu Amaka Natalie, Obende Theresa Owanza, Falaju Idowu Francis, Jacintal Elemere, Obilor Ifeoma Lauretta, Edward Akinwale, and Inalegwu Ochai; from the AFRICOS Mbeya, Tanzania team: John Njegite, Connie Lueer, Abisai Kisinda, Jaquiline Mwamwaja, Faraja Mbwayu, Gloria David, Mtasi Mwaipopo, Reginald Gervas, Dorothy Mkondoo, Paschal Kiliba, Gwamaka Mwaisanga, Johnisius Msigwa, Hawa Mfumbulwa, Peter Edwin, Willyhelmina Olomi.

\section{Disclaimer}

The views expressed are those of the authors and should not be construed to represent the positions of the US Army or the Department of Defense. The investigators have adhered to the policies for protection of human subjects as prescribed in Army Regulation 70-25. (DOD). This research has been supported by the President's Emergency Plan for AIDS Relief (PEPFAR) through the U.S. Department of Defense.

\section{Authors' contributions}

$N S, E B, A E, C P$ and $D R$ conceived of the presented research idea. EB, LM, SK, AL, $H K, J O, J M, M I, A P$ and NS carried out the data collection, laboratory activities and reviewed the collected data for quality and reliability. AE, ND, and DR designed the model and the computational framework and analysed the data. $N S, E B, A E, T C, N D$ and $C P$ contributed to the interpretation of the results. NS took the lead in writing the manuscript. CP and JA were in charge of overall direction and planning. All authors provided critical feedback and helped shape the research, analysis and manuscript. All authors read and approved the final manuscript.

\section{Funding}

This work was supported by the President's Emergency Plan for AIDS Relief via a cooperative agreement between the Henry M. Jackson Foundation for the Advancement of Military Medicine, Inc., and the U.S. Department of Defense [W81XWH-11-2-0174, W81XWH-18-2-0040].

\section{Availability of data and materials}

The Henry M. Jackson Foundation for the Advancement of Military Medicine (HJF) and the Water Reed Army Institute of Research (WRAIR) are committed to safeguarding the privacy of research participants. Distribution of data will require compliance with all applicable regulatory and ethical processes, including establishment and approval of an appropriate data-sharing agreement. To request a minimal data set, please contact the data coordinating and analysis center (DCAC) at PubRequest@hivresearch.org and indicate the RV329 study along with the name of the manuscript.

\section{Declarations}

\section{Ethics approval and consent to participate}

The study was approved by the institutional review boards of the Walter Reed Army Institute of Research, the University of California San Francisco, the
Makerere University School of Public Health, Kenya Medical Research Institute, the Tanzania National Institute of Medical Research, and the Nigerian Ministry of Defense. All participants provided written informed consent.

\section{Consent for publication}

Not applicable.

\section{Competing interests}

The authors declare that they have no competing interests.

\section{Author details}

${ }^{1}$ HJF Medical Research International, Mbeya, Tanzania. ${ }^{2}$ U.S. Military HIV Research Program, Walter Reed Army Institute of Research, Silver Spring, MD, USA. ${ }^{3}$ Henry M. Jackson Foundation for the Advancement of Military Medicine Inc., 6720a Rockledge Drive, Suite 400, Bethesda, MD 20817, USA. ${ }^{4} \mathrm{HJF}$ Medical Research International, Abuja, Nigeria. ${ }^{5}$ Makerere University Walter Reed Project, Kampala, Uganda. ${ }^{6} \mathrm{HJF}$ Medical Research International, Kericho, Kenya. ${ }^{7}$ U.S. Army Medical Research Directorate - Africa, Kisumu, Kenya. ${ }^{8} \mathrm{HJF}$ Medical Research International, Kisumu, Kenya. ${ }^{9}$ National Institute for Medical Research - Mbeya Medical Research Center, Mbeya, Tanzania.

\section{Received: 4 June 2021 Accepted: 11 November 2021}

\section{Published online: 25 November 2021}

\section{References}

1. Ford N, Calmy A, Mills EJ. The first decade of antiretroviral therapy in Africa. Vol. 7, Globalization and Health. 2011.

2. Ndou TV., Maputle SM, Risenga PR. HIV-positive patients' perceptions of care received at a selected antiretroviral therapy clinic in Vhembe district, South Africa. African J Prim Heal Care Fam Med. 2016;8(2):1-6.

3. Hardon AP, Akurut D, Comoro C, Ekezie C, Irunde HF, Gerrits T, et al. Hunger, waiting time and transport costs: time to confront challenges to ART adherence in Africa. AIDS Care - Psychol Socio-Medical Asp AIDS/HIV. 2007;19(5):658-65.

4. Understanding Fast-Track Accelerating Action to End the AIDS Epidemic by 2030. 2015.

5. Lima VD, Harrigan R, Bangsberg DR, Hogg RS, Gross R, Yip B, et al. The combined effect of modern highly active antiretroviral therapy regimens and adherence on mortality over time. J Acquir Immune Defic Syndr. 2009:50(5):529-36.

6. Usman SA, Shehu A, Ajumobi O, Gidado S, Dalhatu I, Balogun M, et al. Predictors of non-adherence to antiretroviral therapy among HIV patients in secondary health care facilities in Kano State- Nigeria: a case-control study. Pan Afr Med J. 2019;32:3.

7. Fleischer L, Avery A. Adhering to antiretroviral therapy: A qualitative analysis of motivations for and obstacles to consistent use of antiretroviral therapy in people living with HIV. SAGE Open Med. 2020:8:205031212091540.

8. Langebeek N, Gisolf EH, Reiss P, Vervoort SC, Hafsteinsdóttir TB, Richter C, et al. Predictors and correlates of adherence to combination antiretroviral therapy (ART) for chronic HIV infection: a meta-analysis. BMC Med. 2014 Aug;12:142.

9. Reda AA, Biadgilign S. Determinants of adherence to antiretroviral therapy among HIV-infected patients in Africa. AIDS Res Treat. 2012;2012:574656.

10. Bijker R, Jiamsakul A, Kityo C, Kiertiburanakul S, Siwale M, Phanuphak P, et al. Adherence to antiretroviral therapy for HIV in sub-Saharan Africa and Asia: a comparative analysis of two regional cohorts. J Int AIDS Soc. 2017:20(1):21218.

11. Mwangi R, Chandler C, Nasuwa F, Mbakilwa H, Poulsen A, Bygbjerg IC, et al. Perceptions of mothers and hospital staff of paediatric care in 13 public hospitals in northern Tanzania. Trans R Soc Trop Med Hyg. 2008;102(8):805-10.

12. Hirschhorn LR. Ensuring quality of care in the scale-up of HIV care and treatment in resource-limited settings: a challenge for all. Therapy. 2007:4(6):737-44.

13. Hargreaves S, Rustage K, Nellums LB, Bardfield JE, Agins B, Barker $P$, et al. Do quality improvement initiatives improve outcomes for patients in antiretroviral programs in low- and middle-income 
countries? A systematic review. JAIDS J Acquir Immune Defic Syndr. 2019;81(5):487-96.

14. The Lancet Global Health. Are we ready for a quality revolution? Lancet Glob Health. 2018;6:e121.

15. Nwabueze SA, Adogu PO, llika AL, Asuzu MC, Adinma ED. Perception of quality of care in HIV/AIDS programmes among patients in a tertiary health care facility in Anambra State. Niger J Med. 2011;20(1):144-50.

16. Dansereau E, Masiye F, Gakidou E, Masters SH, Burstein R, Kumar S. Patient satisfaction and perceived quality of care: evidence from a cross-sectional national exit survey of HIV and non-HIV service users in Zambia. BMJ Open. 2015;5(12):e009700.

17. Ake JA, Polyak CS, Crowell TA, Kiweewa F, Semwogerere M, Maganga L, et al. Noninfectious comorbidity in the African cohort study. Clin Infect Dis. 2019:69(4):639-47.

18. Anosike A, Olakunde BO, Adeyinka DA, Ezeokafor C, Amanze O, Mathews $\mathrm{O}$, et al. Clients' satisfaction with HIV treatment and care services in Nigeria. Public Health. 2019;167:50-4.

19. Purnell L. Reducing waiting time in emergency department mage. Nurs Manage. 1995;26(9):64Q.

20. Lim HC, Tan CB, Goh LG, Ling SL. Why do patients complain? A primary health care study. Singap Med J. 1998;39(9):390-5.

21. Dzansi G, Tornu E, Chipps J. Promoters and inhibitors of treatment adherence among HIV/AIDS patients receiving antiretroviral therapy in Ghana: Narratives from an underserved population. PLOS ONE. 2020;15(3):1-14.

22. Olowookere SA, Fatiregun AA, Ladipo MMA, Akenova YA. Reducing waiting time at a Nigerian HIV treatment clinic: opinions from and the satisfaction of people living with HIV/AIDS. J Int Assoc Physicians AIDS Care. 2012;11(3):188-91.

23. Miller JS, Mhalu A, Chalamilla G, Siril H, Kaaya S, Tito J, et al. Patient satisfaction with HIV/AIDS care at private clinics in Dar es Salaam, Tanzania. AIDS Care. 2014;26(9):1150-1154.
24. Ramchandani SR, Mehta SH, Saple DG, Vaidya SB, Pandey VP, Vadrevu R, et al. Knowledge, attitudes, and practices of antiretroviral therapy among HIV-infected adults attending private and public clinics in India. AIDS Patient Care STDS. 2007;21 (2):129-42.

25. Moyo F, Chasela C, Brennan AT, Ebrahim O, Sanne IM, Long L, et al. Treatment outcomes of HIV-positive patients on first-line antiretroviral therapy in private versus public HIV clinics in johannesburg, South Africa. Clin Epidemiol. 2016;8:37-47.

26. Ahmad BA, Khairatul K, Farnaza A. An assessment of patient waiting and consultation time in a primary healthcare clinic. Malaysian Fam Physician. 2017;12(1):14-21.

27. McKinnon K, Crofts PD, Edwards R, Campion PD, Edwards RHT. The outpatient experience: Results of a patient feedback survey. Int J Health Care Qual Assur. 1998;11(5):156-60

28. Yeddula VR. Healthcare Quality: Waiting Room Issues. 2012;1-89.

29. Dang BN, Westbrook RA, Black WC, Rodriguez-Barradas MC, Giordano TP. Examining the link between patient satisfaction and adherence to HIV care: a structural equation model. PLoS ONE. 2013;8(1):54729.

30. Brincks AM, Shiu-Yee K, Metsch LR, del Rio C, Schwartz RP, Jacobs P, et al. Physician mistrust, medical system mistrust, and perceived discrimination: associations with HIV care engagement and viral load. AIDS Behav. 2019;23(10):2859-69.

31. Leon C, Koosed T, Philibert B, Raposo C, Benzaken AS. HIV/AIDS health services in Manaus, Brazil: patient perception of quality and its influence on adherence to antiretroviral treatment. BMC Health Serv Res. 2019;19(1):1-12.

\section{Publisher's Note}

Springer Nature remains neutral with regard to jurisdictional claims in published maps and institutional affiliations.
Ready to submit your research? Choose BMC and benefit from:

- fast, convenient online submission

- thorough peer review by experienced researchers in your field

- rapid publication on acceptance

- support for research data, including large and complex data types

- gold Open Access which fosters wider collaboration and increased citations

- maximum visibility for your research: over 100M website views per year

At BMC, research is always in progress.

Learn more biomedcentral.com/submissions 